Agnieszka Szpak

Nicolaus Copernicus University in Toruń (Poland)

\title{
Amnesties: conditio sine qua non for a Lasting Peace Solution or Ticking Time Bomb for Peacebuilding?
}

\begin{abstract}
The author attempts to define amnesty and describe conditions that must be met for amnesties to be in accordance with international law. This in turn involves an analysis of legality of amnesties. The paper also examines motivation for granting amnesty and desirability as well as the future of granting amnesties. In the end a nuanced approach is adopted highlighting the fact that amnesties are neither conditio sine qua non for a lasting peace solution nor ticking time-bombs for peacebuilding. This reflects the idea of this paper that justice is not an absolute and sometimes it might be necessary to let go and combine judicial and non-judicial mechanisms (including the disclosure of truth and reparations for the victims) in order to achieve sustainable peace.
\end{abstract}

Keywords: amnesty; peacebuilding; international crimes; impunity; peace

\section{Introduction}

Amnesties remain the feature of contemporary armed conflicts as evidenced by the recent amnesties granted in Ukraine and Colombia. They raise huge controversies as they block the prosecution and punishment of the perpetrators of human rights and international humanitarian law violations. On the other hand they may contribute to reconciliation and peacebuilding in communities torn apart by wars. Today amnesties are not only an act of forgetfulness or oblivion but also 'a means of remembrance' (Ntoubandi, 2007: 229) with regard to the past. According to Mark Freeman, amnesty is an extraordinary legal measure which primary function is to remove the prospect and consequences of criminal liability for designated individuals or classes of persons in respect of designated types of offences irrespective of whether the persons concerned have been tried for such offences in a court of law' (2009: 13, Ntoubandi, 2007: 9-12).

Amnesties and transitional justice fit into the legal aspect of peacebuilding. Peacebuilding was defined in the Agenda for Peace of 1992 as an 'action to identify and support structures which will tend to strengthen and solidify peace in order to avoid a relapse into conflict' 
(para. 21). It may include disarmament of the belligerents, restoring order, repatriating refugees, training and advising security forces, monitoring elections, bringing back respect for human rights, reforming government institutions or strengthening them, and promoting formal or informal participation in the State governance (Agenda for Peace, 1992, para. 55). Its practical application includes - relevant in the context of this article - holding the perpetrators of international crimes responsible for their actions (Šimonović, 2003: 254-256; Barnett, Kim, O’Donnell, Sitea, 2007: 49-50).

Societies transitioning from a conflict situation to the state of peace have two alternatives with regard to human rights violations and crimes against humanity: retributive justice and restorative justice. The former one includes punishing perpetrators by the way of criminal trials and the latter extrajudicial (non-penal) attitude emphasising the need for revealing the truth, for example before truth commissions or other appropriate bodies. In each of these options revealing the truth about past crimes is a necessary step to build sustainable peace (Mullenbach, 2006: 57-59).

Recent examples include amnesties in Ukraine and in Colombia of 2016 that were part of the strategy to end armed conflicts in those States (in case of Ukraine the amnesty pertains only to minor offences committed by the Ukrainian soldiers participating in the Anti-Terrorist Operation in the east Ukraine - Poroshenko signs long-awaited law on amnesty for Ukraine soldiers with minor offences, 2017: on-line); amnesty in Uganda declared in 2000 in order to encourage defection by rebel forces (it was extended in June 2015 for a further period of two years); amnesty in Mali of 2012 that resulted in a release of number of perpetrators of serious crimes as a part of the peace process (Close 1,2016: 1; Mali coup leader charged with murder, 2013: on-line).

On the one hand, amnesties give rise to lots of controversies as they may lead to incompatibility with the obligation to prosecute and punish serious violations of human rights and international humanitarian law and - as a result - create the atmosphere of impunity. On the other hand, amnesties may be regarded as an instrument of peacebuilding which encourages peace and reconciliation. Having this dilemma in mind (often called peace v. justice) I will attempt to examine the meaning of transitional justice and its elements and how amnesties fit into this framework. I will also briefly analyse the legality of amnesties and reasons for granting them. In various places of the text there are mentioned some examples of amnesties, including one of the most recent and hotly debated conditional amnesty in Colombia. Actually, the article focuses on the Colombian case and other cases are used by the way of illustrating general conceptual arguments. The article ends with some concluding remarks including the ones on the desirability of enacting amnesties in the future. There I also refer to the question posed in the title of this article: are the amnesties conditio sine qua non for a lasting peace solution or ticking time-bombs for peacebuilding?

The sources used in this article comprise relevant literature on the subject of amnesties in the framework of transitional justice and peacebuilding as well as relevant jurisprudence of the Inter-American and European Courts of Human Rights. Research methods involve 
content analysis with regard to the examined literature and legal analysis of the referenced jurisprudence.

\section{Transitional justice and punishment of the international criminals}

The term 'transitional justice' has emerged in the 1990's. It embraces the punishment of the perpetrators of serious crimes, revealing the truth about such crimes, the compensation of the victims, the reform of oppressive institutions and reconciliation. Transitional justice may take the form of retributive justice, restorative justice (including traditional mechanisms of dispute resolution), amnesties, truth and reconciliation commissions and compensation programmes of the victims (as a form of justice without formal punishment of perpetrators), commemorating the victims as well as security sector and police reform in order to prevent security and police apparatus from violating human rights in the future (Huyse, 2003: 108; Komosa, 2014: 31). It involves complex strategies that must take into account the consequences of past events but must also be forward-looking in order to prevent armed conflicts from recurring. As Mark Freemen notes, ' $t \mathrm{t}$ ] ransitional justice focuses on the challenge of confronting legacies of mass abuse. Its methods and approaches typically apply in societies in transition from war to peace, or from authoritarian rule to democracy [...]' (2009: 18). Transitional justice may be imperative after the political transformation in a State and after the end of armed conflict - as a part of the peacebuilding efforts. I am interested in the latter one. In this context one category of amnesties is relevant, namely that of pacification amnesty. So called pacification amnesties are

adopted during or at the end of an armed conflict for the purpose of creating conditions conducive to a peace process. Pacification amnesties have often been introduced by a peace treaty, either between warring states or between a national government and rebel armed groups (Close 1, 2016: 163).

This concept assumes that justice is not absolute and it must be balanced with the need for peace, democracy and economic development (Wiatr, 2009: 366). Examples of pacification amnesties include, among others, amnesties granted in: El Salvador in 1993, the South Africa (the Promotion on National Unity and Reconciliation Act) in 1995, Uganda (Amnesty Act) in 2000 (Peace First, Justice Later, 2005: 3-4, 30-32; Huyse \& Salter, 2008: 95-97; O'Shea, 2004: 39-42) and in Nepal (Truth and Reconciliation Commission Ordinances) in 2013 and 2014. All of these measures included amnesties for serious crimes (Close 1, 2016: 195). One can add limited and conditional amnesties in Ukraine and Colombia.

As transitional justice is very often implemented in difficult conditions of unstable peace, its strategies must strike a balance between the requirements of justice and realistic short term and long term capabilities. In the last decade transitional justice has evolved in many respects. Firstly, today transitional justice is not merely an ideal or aspiration but it is reflected in legally binding 
norms. Human rights law - particularly expressed in the jurisprudence of the European Court of Human Rights, Inter-American Commission and Court of Human Rights and Human Rights Committee - has evolved and today it reached somelevel of maturity meaning that clear standards in the sphere of human rights abuses and corresponding State obligations have been established (van Zyl,2005: 209; Mallinder, 2016:645-680). According to Paul van Zyl, this refers to

blanket amnesties for international crimes. This has been supported by the ratification of the International Criminal Court (ICC) by over 100 countries [123 as of the time of writing] which has both reinforced existing obligations and created new standards, by requiring each signatory to respond appropriately to human rights abuse or face action by the court (2005: 209-210).

\section{Legality of amnesties}

In a separate opinion appended to the judgment issued by the Special Court for Sierra Leone Justice Robertson observed that there has been an important change in the international community's approach to amnesty 'from regarding it as the blessing of forgiveness to reproaching it as the curse of impunity' (Prosecutor v. Allieu Kondewa, on-line: para. 33). Actually it was only in the 1990's that 'claims alleging the impermissibility of amnesties for serious crimes started to emerge in public discourse' (Close 1,2016: 101). At that time the UN policy of rejecting amnesties applying to serious crimes has emerged (Close 1, 2016: 170). International policy and judicial development contributed to such voices. This tendency is illustrated by the words of the report of the UN Secretary General to the Security Council The rule of law and transitional justice in societies that suffer or have suffered conflicts where the Secretary General noted that: '[...] United Nations tribunals can never allow for capital punishment, United Nations-endorsed peace agreements can never promise amnesties for genocide, war crimes, crimes against humanity or gross violations of human rights [...]' (Report of the Secretary General of the United Nations. The rule of law and transitional justice, 2004, on-line: para. 10).

However, it should be stressed that neither the International Criminal Court (ICC) Statute nor any other international treaty expressly prohibits granting amnesties, even for serious international crimes. During the preparatory works on the ICC Statute of 1998 and on the International Convention for the Protection of All Persons from Enforced Disappearance of 2006 discussions as to the need for such a prohibition were held but - due to the divergent opinions of States - this issue was dropped out. The only treaty provision expressly referring to amnesty is Art. 6 (5) of the II Additional Protocol to the Geneva Conventions of 1977 which states that

[a]t the end of hostilities, the authorities in power shall endeavour to grant the broadest possible amnesty to persons who have participated in the armed conflict, or those 
deprived of their liberty for reasons related to the armed conflict, whether they are interned or detained (on line).

However, even though the ICC Statute is silent on the issue of amnesty, it is worth mentioning that amnesty declared in any of the ICC Statute States-parties may be examined at the admissibility stage. The ICC has a complementary jurisdiction that it exercises only when a State-party is unwilling or unable to conduct a trial (art. 17; ICC Statute, 1998: on-line). Depending on the circumstances of each case, it is possible to establish that amnesty was granted specifically to shield a suspect from criminal prosecution for crimes falling within the ICC jurisdiction and accordingly such an amnesty would not prevent the ICC from investigating the case. It should definitely apply to blanket amnesties for serious international crimes but it may even apply to conditional amnesties as well. The future ICC practice will be decisive (Scharf, 1999: 507-527). Thus, as Marcin Komosa argues, in the case of the ICC proceedings or the exercise by a third State of universal jurisdiction, conditional amnesty may not be a bar to the admissibility of the charges. Amnesty as a mechanism used by the truth commission is valid but only in the State convening such a commission and on conditions envisaged in its mandate (2014:353). One may also add that the Statutes of the Special Court for Sierra Leone (on line: art. 10), the Special Tribunal for Lebanon (on-line: art. 6) and the Extraordinary Chambers in the Courts in Cambodia (Law on the Establishment of the Extraordinary Chambers, on-line: art. 40) expressly provided that amnesties may not deprive the tribunals and chambers of jurisdiction over serious crimes. The statutes of the International Criminal Tribunals for the former Yugoslavia and for Rwanda are silent on the issue of amnesty but it only signals the consensus in this area, namely that of excluding any amnesties.

Josepha Close examined whether there is in international law a treaty norm prohibiting amnesties applying to serious crimes. And the answer was no, there is no convention expressly prohibiting such amnesties. The same conclusion flows from the examination of the State practice and accompanying opinio iuris, although such a norm is slowly emerging (Close 1,2016:2, 161, 288, 295). However, because of the risk of impunity for the perpetrators of serious crimes, such crimes should be excluded from the ambit of amnesty. Granting such amnesties will not prevent the recurrence of violations and will not facilitate national reconciliation. A part of the peacebuilding includes transitional justice and punishing the perpetrators of crimes, hence amnesties for serious international crimes do not serve peacebuilding. In such a case there is clear 'incompatibility between a commitment to punish a crime and the exoneration of its perpetrator through an amnesty' (Close 1, 2016: 159). Faustin Z. Ntoubandi argues that amnesties for crimes against humanity are illegal and invalid as they are in clear violation of international law (2007: 228-229; see also: Engle, 2016: 24-67; Princeton Principles on Universal Jurisdiction, 2001: on-line, principle 7). In all of the cases relating to serious crimes a trend and a norm is emerging that it is necessary to distinguish between legal and illegal amnesties. Accordingly, illegal amnesties 
are blanket amnesties that unconditionally stop investigations and allow for the impunity of criminals. Legal amnesties, in turn, are aimed at creating institutional conditions and the minimal level of security necessary for respect for human rights and that require from the perpetrators an active participation in establishing the truth, ensuring an accountability and compensation (Belfest Guidelines on Amnesty, 2013: 9-10). Despite granting the amnesty, investigations into the alleged violations must be conducted as the victims and the society at large have the right to know the truth. Compensation for violations must as well be ensured to the victims.

\section{Motives and preconditions for granting amnesties}

The main motives for granting amnesties are national reconciliation, reunification and the maintenance of social peace and harmony (Ntoubandi, 2007: 13-15). As Josepha Close rightly argues,

[a]t the end of hostilities, it is desirable that normal life should be resumed as soon as possible. Hence, it would be fitting to generalize the proclamation of general amnesty, in the interest of both the victims and the authorities who will have to restore order and reconcile all elements of a divided people $(1,2016: 128)$.

\section{Accordingly,}

[i]t seems that only amnesties forming part of a broader process aimed at establishing conditions conducive to peace, truth or reconciliation and entailing the conduct of investigation, the establishment of a credible alternative accountability system and the compensation of the victims may be deemed acceptable and in accordance with human rights of the victims (Close 1,2016: 149). [...] Even though some international courts and tribunals have rejected the possibility of granting amnesties applying to serious crimes, there is as yet [...] no prohibition on amnesties even for serious crimes. Accordingly, even when amnesties are granted for serious crimes, they may be deemed acceptable when they are enacted as a part of peace building process - in the interest of peace or reconciliation and when they, at the same time, provide for a certain degree of accountability and reparation for the victims (Close 1, 2016: 226).

One may point to seven motives for granting amnesty: the mitigation of internal unrest; building peace and internal reconciliation; a response to international pressure; religious and cultural factors; compensation for damage done by the authorities; incentive for refugees to return and ensuring impunity for State officials (so called self-amnesty) (Komosa, 2014: 170). Belfast Guidelines on Amnesty and Accountability indicate that during armed conflicts 
or within transitional justice framework amnesty may be granted in order to achieve such positive effects as:

encouraging combatants to surrender and disarm, persuading authoritarian rulers to hand over power, building trust between warring factions, facilitating peace agreements, releasing political prisoners, encouraging exiles to return, providing an incentive to offenders to participate in truth recovery or reconciliation programmes (2013: 9).

For instance, in the Sierra Leone Lomé peace agreement amnesty was regarded as a necessary prerequisite for the parties to the civil war to even start peace negotiations. The war would not end without guarantying the rebels amnesty for serious crimes (Close 1, 2016: 182).

Conditions that may be set for perpetrators that want to be granted amnesty include:

submitting individual applications, surrendering and participating in disarmament, demobilization and reintegration programmes, participating in traditional or restorative justice processes, fully disclosing personal involvement in offences, with penalties for false testimony, providing information on third party involvement with respect to offences, testifying (publicly or privately) in a truth commission, public inquiry or other truth-recovery process, testifying at the trial of those who were not granted or eligible for amnesty, surrendering assets illegitimately acquired, contributing materially and/ or symbolically to reparations (Close 1,2016: 17-18).

On the other hand, the authors of a handbook on the Reconciliation After Violent Conflict point that post-conflict communities may resign from the criminal trial of the perpetrators of serious international crimes but on certain conditions such as:

- Blanket amnesties are unacceptable;

- Irrefutable proof must be given that national courts are unable to conduct criminal trials;

- All population, in particular the victims, must take part in making the decision on resigning from criminal trials;

- State authorities must pledge to recognise - as widely as possible - the truth about the past;

- Victims must be given a fair compensation;

- Those that will be granted amnesty must express their regret for their actions (Huyse, 2003: 108).

Unconditional amnesties are rarely granted. Usually the following conditions must be met:

- Amnesty only after the full disclosure by the perpetrator of relevant facts (as in the South Africa case); 
- Amnesty available only for certain categories of perpetrators (for example, childsoldiers);

- Amnesty available for crimes committed in a certain timeframe;

- Amnesty that excludes crimes that, according to international law, are not susceptible to amnesty (for example, torture) (Huyse, 2003: 110).

For instance, in Sierra Leone it was decided that amnesty will be granted to all the military accused of endangering the national security (Negotiating Justice? Human Rights and Peace Agreements, 2006: 85).

Declarations of amnesty are criticised mainly for their negative impact on respect for human rights. It has been noted that amnesties contribute to the state of impunity. But the authors of the Belfast Guidelines on Amnesty and Accountability argue that - when formulating such charges - the different kinds of amnesties and accompanying conditions are not taken into account. Their research shows that there is no proof of the negative impact of amnesties on the respect for human rights. The examples of Spain and Mozambique proved that even amnesties granted to perpetrators of serious crimes may be a part of the transitional process to stable democracies and to respect for human rights. These examples indicate that amnesties not necessarily have a negative impact on the respect for human rights (Belfast Guidelines on Amnesty, 2001:27-28). Another positive example is that of Angola which, as well, shows that even though the perpetrators of serious crimes were not punished, amnesty in this country contributed to peace and reconciliation (Close 1,2016: 187). On the other hand there are scholars like Victor Igreja who present a different point of view:

[t]he analysis reveals complex realities that defy mainstream praise for the amnesty law and the allegedly successful peacebuilding in Mozambique. It suggests that Frelimo [Frente de Libertação de Moçambique] alone passed the amnesty law to avoid accountability and to imply public commitment to reconciliation in tandem with their attempt to recover losses incurred in the peace negotiation context. These goals fostered the marked open-endedness of the transition, whereby contested war memories were used as weapons and fierce struggles for political legitimacy involving flashes of political violence occurred well beyond the accord (2015: 239).

Amnesties combined with other instruments of transitional justice may bring about positive results in the peacebuilding efforts, including reconciliation. In my opinion, amnesties should not be granted for serious international crimes, especially to perpetrators bearing the greatest responsibility, or they may be granted only exceptionally if such is the will of the community concerned and the reparation to the victims is ensured. The responsibility of perpetrators does not have to be limited to its criminal form. It should be added that amnesties passed as law by democratically elected governments or parliaments are more legitimate than self-amnesties declared by the authoritarian regimes without any public debate (Freeman, 2009: 13). 
Josepha Close enumerates the following examples of amnesties expressly referring to reconciliation:

- the Lusaka Protocol (Angola) of 15 November 1994 that states: '[i]n the spirit of National Reconciliation, all Angolans should forgive and forget the offenses resulting from the Angolan conflict and face the future with tolerance and confidence';

- the Protocol on the Main Functions and Powers of the Commission on National Reconciliation (Tajikistan) of 23 December 1996 that provides that the aim of the amnesty should be 'the attainment of national reconciliation' and 'the creation of an atmosphere of trust and mutual forgiveness, and the institution of a broad dialogue among the various political forces in the country in the interests of the restoration and strengthening of civil accord in Tajikistan';

- the Lomé Peace Agreement adopted in the context of the armed conflict in Sierra Leone on 7 July 1999 defines the aim of the general amnesty as ' $[t]$ o consolidate the peace and promote the cause of national reconciliation' (art 9) (Close 1,2016: 166).

One of the most vividly commented examples of amnesties today is the Final Accord for the Termination of the Conflict and the Construction of a Stable and Lasting Peace in Colombia signed on 24 November 2016 (on-line). According to this document, one the one hand, amnesty would be granted for political crimes and related crimes such as rebellion, sedition, mutiny, legal acts of war such as the lawful killing of enemy combatants and illegal possession of weapons. On the other hand, it excludes from its ambit crimes against humanity, war crimes, torture, taking of hostages, enforced disappearances, extrajudicial executions, sexual crimes and recruitment of child soldiers (Close 2, 2016: on-line). Still, the perpetrators of serious crimes may benefit from an alternative - an imprisonment - punishment embracing reparative labour and certain restrictions on their freedom of movement. It will be possible under two conditions: first, the perpetrator must reveal his or her crimes and acknowledge responsibility for it, and second, they must agree to a reparation project lasting about 5-8 years. If perpetrators do not submit to those conditions they may be sentenced to maximum 20 years in prison (Close 2, 2016: on-line). The Colombian peace agreement seems to be balanced as it takes into account the rights of the victims to know the truth, to reparation and to justice and, at the same time, it allows for reconciliation and inclusion of the perpetrators back in the community. As Josepha Close notes, ' $[\mathrm{t}]$ he Colombian alternative accountability system may be equated with a conditional amnesty in so far as it requires offenders to fulfil certain conditions in order to avoid criminal punishment' (Close 2, 2016: on-line).

With reference to Colombia or any other country torn apart by an internal armed conflict, it is worth pointing out to a very important opinion of Judge Garcia-Sayàn expressed in his concurring opinion in the El Mozote v. El Salvador judgment of the Inter-American Court of Human Rights (2012) that was adhered to by four other judges:

A negotiated solution to the internal armed conflict raises several issues regarding the weighing of these rights [of the victims], within the legitimate discussion on the need 
to conclude the conflict and put an end to future serious human rights violations. States have a legal obligation to address the rights of the victims and, with the same intensity, the obligation to prevent further acts of violence and to achieve peace in an armed conflict by the means at its disposal. Peace as a product of a negotiation is offered as a morally and politically superior alternative to peace as a result of the annihilation of the opponent. Therefore, international human rights law should consider that peace is a right and that the State must achieve it. Thus, in certain transitional situations between armed conflicts and peace, it can happen that a State is not in a position to implement fully and simultaneously, the various international rights and obligations it has assumed. In these circumstances, taking into consideration that none of those rights and obligations is of an absolute nature, it is legitimate that they be weighed in such a way that the satisfaction of some does not affect the exercise of the others disproportionately. Thus, the degree of justice that can be achieved is not an isolated component from which legitimate frustrations and dissatisfactions can arise, but part of an ambitious process of transition towards mutual tolerance and peace (2012: paras. 37-38).

This statement is extremely significant as it, first of all, points to the extraordinary circumstances for granting amnesties and to a need to achieve some compromise between peace and justice. It reflects the essence and core of the amnesty controversies. Anyway, the will of the people concerned should be a decisive factor here. Colombia example is again instructive. It proves that the will of the people combined with the engagement of all the relevant internal and international actors may contribute to the positive role of amnesty in peacebuilding efforts, including reconciliation. In this case the peace plan with conditional amnesty as its part was undermined by the opposition to this plan, including the former president Alvaro Uribe who - for political reasons - misinformed the voters and manipulated them into voting 'no' to the recent peace plan with FARC (the turnout was very low - about $37 \%$ and the majority against very small - 50,2 \%) (Sánchez, 2016: on-line). As Carlos Fonseca Sánchez claimed:

[p]olitical opponents of the peace deal successfully used a handful of assertions to move the population against the agreement. They took advantage of the long and sometimes ambiguous text to raise concerns regarding impunity. They also argued that the agreement would harm the integrity of family values [abolish the catholic family model], a position that moved many Christian pastors to oppose the treaty. Surprisingly, the chief of campaign for the "no" has recognized the manipulations used to influence people. He stated that it was the cheapest and most effective campaign in history and that the "no" strategy was directed to generate indignation amongst the voters. He also acknowledged that the use, and abuse, of social media proved fruitful to them (on-line). 
Former Colombian president Álvaro Uribe threatened that the peace agreement 'would turn Colombia into the next Venezuela; [...] that the purpose of the agreements was to abolish private property; he [also] accused the government of negotiating his own imprisonment with the guerrillas' (Vásquez, 2016: on-line). The main reasons for this negative vote were the sense of impunity of the FARC members and the fact of the automatic political representation of FARC in the Congress (Diaz \& Robledo, 2016: on-line). What is important, people from the provinces mostly affected by the armed conflict voted in favour of the peace deal and one could assert that their opinion is indeed the voice/will of the people (Colombia referendum: Voters reject Farc peace deal, 2016: on-line). Despite the rejection of the initial peace accord the Colombian President decided to continue the work on the peace agreement and the Colombian Congress amended the Constitution in order to implement the peace deal. Due to the amendments the new law 'envisage[d] the creation of a holistic justice system aimed at unifying Colombia's scattered transitional justice landscape. The emphasis is not so much on retribution but rather on establishing the truth about the past, creating mechanisms for reparations for victims and guarantees of non-repetition' (Aksenova, 2017: on-line). A Colombian transitional justice framework is thus composed most of all of the Truth Commission, the Unit for the Search of Missing Persons and the Special Jurisdiction for Peace (SJP). SJP is competent to choose between ordinary and alternative sanctions for the FARC members. As already mentioned, the alternative penalty is understood as restriction of the liberty meaning 'sentencing persons to reside within a designated demobilization zones' (called Transitional Local Zones for Normalisation) for a period from 5 to 8 years (Aksenova, 2017: on-line). This sanction may be combined with reparations to victims and other restorative measures such as infrastructure rebuilding in the areas mostly affected by the conflict or anti-personnel mine clearance (on other restorative measures see: Final Agreement, 2016: section 5.1.3.2). A confession to a crime is necessary for receiving milder punishment (already mentioned alternative penalties), and the character of the penalty will depend on the time of such confession being made: ' $t$ ] hose who confess early in the process are likely to benefit from alternative penalties, while those who confess later during trial face five to eight years of jail time; those who do not acknowledge their responsibility at all risk fifteen to twenty years of imprisonment' (Final Agreement, 2016: section 5.1.2, item 60).

Finally, the peace deal expressly

provides opportunities for reparations. It is well known that FARC acquired significant wealth during conflict, for example through illegal mining. The law creates explicit incentives for FARC to declare their assets to the government (to be later used for reparations) by including them in a special inventory covered by the SJP jurisdiction. Offences relating to assets discovered at a later stage and not on the inventory will be subject to ordinary criminal jurisdiction (Aksanova, 2017: on line; Final Agreement, 2016: section 5.1.3.7). 
Taking all this into account a Colombian case may rather be treated as a conditional amnesty within the framework of transitional justice regulated by section 5 of the Final Agreement.

Going back to the will of the people, still there are cases in which international tribunals determined that the fact that amnesty law was approved in a national referendum was irrelevant and amnesty was unacceptable. This was the conclusion of the Inter-American Court of Human Rights judgment in the Gelman v. Uruguay case (2011) (para. 238) ${ }^{1}$. The same Court expressly stated that self-amnesties and amnesties for serious human rights infringements are incompatible with the American Convention on Human Rights (Barrios Altos v. Peru, 2001: para. 41; Almonacid-Arellano v. Chile, 2006: paras. 112, 114 and 119; Gomes Lund et al. v. Brazil, 2010: para. 175).

The European Court of Human Rights did not have many occasions to deal with amnesty laws but in one case i.e. Marguš v. Croatia determined that amnesties for serious crimes are illegal but it envisaged some exceptions to this rule: when such amnesties serve the interests of reconciliation and some form of reparation is afforded (2014: paras. 130, 139-140). Hence, the Court pointed to the motives for granting amnesties. It added, however, that

[t]he possibility for a State to grant an amnesty in respect of grave breaches of human rights may be circumscribed by treaties to which the State is a party. There are several international conventions that provide for a duty to prosecute crimes defined therein (see the Geneva Conventions of 1949 for the Protection of Victims of Armed Conflicts and their Additional Protocols [...], the Convention on the Prevention and Punishment of the Crime of Genocide; and the Convention Against Torture (para. 132).

\section{Concluding remarks: the future of amnesties}

Amnesties will remain the feature of international justice but they should be tailored to a given situation and take into account the rights of victims. Amnesties may be an instrument capable of achieving regeneration after the mass violence or genocide, even though it rather contributes to peaceful but superficial coexistence (Freeman, 2009: 6). Still, sometimes it is the best option available. The opponents of amnesties argue that they may contribute to impunity and constitute an obstacle to the right of the victims to reparations as well as the right of the victims and the whole community to know the truth as they prevent investigation of the facts and actions undertaken by the perpetrators of serious crimes. As such they are regarded as incompatible with States, obligations to prosecute, try and punish the

${ }^{1}$ Gelman v. Uruguay (Inter-American Court of Human Rights, Judgment of February 24, 2011, Merits and Reparations), para. 238: „The fact that the Expiry Law of the State has been approved in a democratic regime and yet ratified or supported by the public, on two occasions, namely, through the exercise of direct democracy, does not automatically or by itself grant legitimacy under International Law". 
perpetrators of serious violations of human rights and international humanitarian law. The often recalled peace versus justice dilemma is regarded as only apparent because amnesties create the culture of impunity and the punishment of the perpetrators of serious crimes is considered as the necessary element of peacebuilding and healing the communities torn apart by wars. This is the only way to prevent the crimes from being committed again. But there is also another face of amnesty, the one proponents point to. Sometimes it is a measure necessary for successful peacebuilding and reconciliation of those same communities torn apart by armed conflicts. It might be worth the price paid for the end of a war and beginning of peace and reconciliation. This is reflected in the phrase that '[o]ne's priorities [...] shape one's positions' (Freeman, 2009: 7) on amnesties: here comes the justice versus peace dilemma.

The will of the people (expressed in a referendum or in a similar way) should be decisive because people tormented by war know what is best for them. Although there is one caveat: approval or disapproval of amnesty should be expressed in an informed and voluntary way (possibly free of any or at least major outside pressure and manipulation). Generally there might be a need to combine judicial and non-judicial instruments of transitional justice and reparation to the victims, sometimes including amnesty.

I believe that human rights abuses and impunity should be condemned but when the life of people is at stake we should consider granting amnesty if this is necessary to end the killing and torturing people that takes place during wars, which I equally strongly condemn. This would be resorted to in extreme circumstances when formal justice system is not working properly or at all. Based on the foregoing considerations, the answer to the question posed in the title of this article is that amnesties are neither conditio sine qua non for a lasting peace solution nor a ticking time-bomb for peacebuilding. On the one hand, they block the prosecution and punishment of the offenders but, on the other hand, they may contribute to peacebuilding and reconciliation as well as facilitate gradual transition from war to peace. The compromise solution may consist of punishing the perpetrators of serious crimes while the less serious ones could be dealt with within other mechanisms such as the truth and reconciliation commissions. This in turn should be combined with the security sector reform, demobilisation, demilitarisation and reintegration of combatants and other measures tailored to meet the local conditions. Such seems to be the legal trend - allowing for 'limited amnesties and alternative punishments' (Mallinder, 2016: 29). This once again shows that amnesties must be tailored to the concrete local circumstances and take into account the will of the people. Their ultimate aim is to facilitate peacebuilding and reconciliation. 


\section{References}

Additional Protocol II (1977). Retrieved from: https://ihl-databases.icrc.org/ihl/INTRO/475.

Almonacid-Arellano v. Chile (Inter-American Court of Human Rights, Judgment 2006). Retrieved from: http://www.corteidh.or.cr/docs/casos/articulos/seriec_154_ing.pdf.

Aksenova, M. (2017). Achieving Justice Through Restorative Means in Colombia: New Developments in Implementing the Peace Deal. Retrieved from: https://www.ejiltalk.org/achieving-justice-throughrestorative-means-in-colombia-new-developments-in-implementing-the-peace-deal/\#more-15206.

Barnett, M., Kim, H., O’Donnell, M., Sitea, L. (2007). “Peacebuilding: What Is in a Name?”. Global Governance 13, p. 35-58.

Barrios Altos v. Peru (Inter-American Court of Human Rights, Judgment 2001). Retrieved from: http:// www.corteidh.or.cr/docs/casos/articulos/seriec_75_ing.pdf.

Boutros-Ghali B. (1992). An Agenda for Peace. Retrieved from: http://www.un.org/ga/search/view_doc.asp? symbol=A/47/277.

Close 1, J. (2016). The International Legal Status of Amnesties Granted for Serious Crimes: Historical and Contemporary Perspectives, Middlesex: $\mathrm{PhD}$ thesis.

Close 2, J. (2016). Meeting International Standards: Amnesty in the Colombian Peace Deal. Retrieved from: https://justiceinconflict.org/2016/10/14/meeting-international-standards-amnesty-in-the-colombianpeace-deal/.

Colombia referendum: Voters reject Farc peace deal (2016). Retrieved from: https://www.bbc.co.uk/news/ world-latin-america-37537252.

Diaz, F.A., Robledo, V.M. (2016). Uncertainty, Peace Agreements, and Public Participation in Colombia. Retrieved from: http://www.warscapes.com/opinion/uncertainty-peace-agreements-and-publicparticipation-colombia.

Engle, K. (2016). “A Genealogy of the Criminal Turn in Human Rights”. In Engle, K., Miller, Z., Davis D.M. (eds), Anti-Impunity and the Human Rights Agenda (p. 24-67). Cambridge: Cambridge University Press.

"Final Accord for the Termination of the Conflict and the Construction of a Stable and Lasting Peace in Colombia signed on 24 November 2016". Retrieved from: http://especiales.presidencia.gov.co/ Documents/20170620-dejacion-armas/acuerdos/acuerdo-final-ingles.pdf.

Freeman, M. (2009). Necessary Evils: Amnesties and the Search for Justice, Cambridge: Cambridge University Press.

Gelman v. Uruguay (Inter-American Court of Human Rights, Judgment 2011, Merits and Reparations). Retrieved from: http://www.corteidh.or.cr/docs/casos/articulos/seriec_221_ing.pdf.

Gomes Lund et al. v. Brazil (Inter-American Court of Human Rights, Judgment 2010). Retrieved from: Huyse, L. (2003). “Justice”. In Bloomfield, D., Barnes, T., Huyse, L. (eds), Reconciliation After Violent Conflict. A Handbook (p. 97-121), Stockholm: International Institute for Democracy and Electoral Assistance. Huyse, L., Salter M. (eds) (2008). Traditional Justice and Reconciliation after Violent Conflict. Learning from African Experiences, Stockholm: International Institute for Democracy and Electoral Assistance.

ICC Statute (1998). Retrieved from: https://www.icc-cpi.int/nr/rdonlyres/ea9aeff7-5752-4f84be94-0a655eb30e16/0/rome_statute_english.pdf.

Igreja, V. (2015). "Amnesty Law, Political Struggles for Legitimacy and Violence in Mozambique". International Journal of Transitional Justice 9 (2), p. 239-258.

Komosa, M. (2014). Komisja prawdy. Mechanizm odpowiedzialności za naruszenie praw człowieka, Warsaw: Wydawnictwo Uniwersytetu Warszawskiego. 
"Law on the Establishment of the Extraordinary Chambers". Retrieved from: https://www.eccc.gov.kh/ en/document/legal/law-on-eccc.

Mali coup leader charged with murder (2013). Retrieved from: https://mobile.nation.co.ke/news/Malicoup-leader-charged/-/1950946/2090972/-/format/xhtml/item/1/-/11vnsnpz/-/index.html.

Mallinder, L. (2016). “The End of Amnesty Regional Overreach? Interpreting the Erosion of South Africa's Amnesty Laws”. International and Comparative Law Quarterly 3, p. 645-680.

Marguš v. Croatia (European Court of Human Righjts, Judgment 2014). Retrieved from: http://www. corteidh.or.cr/docs/casos/articulos/seriec_219_ing.pdf http://hudoc.echr.coe.int/eng (accessed 01.06.2017).

Mullenbach, M.J. (2006). "Reconstructing strife-torn societies. Third-party peacebuilding in intrastate disputes”. In Mason, T. D., Meernik, J. D. (eds), Conflict Prevention and Peacebuilding in Post-War Societies. Sustaining the Peace (p. 53-80). New Jork-London: Routledge Taylor \& Francis Group.

Negotiating Justice? Human Rights and Peace Agreements (2006), International Council on Human Rights Policy. Retrieved from: http://www.ichrp.org/files/reports/22/128_report_en.pdf.

Ntoubandi, F.Z. (2009). Amnesty for Crimes against Humanity under International Law, Leiden: Brill.

O'Shea, A. (2004) Amnesty for Crimes in International Law and Practice, The Hague.

Poroshenko signs long-awaited law on amnesty for Ukraine soldiers with minor offences (2017). Retrieved from: https://www.unian.info/war/2113281-poroshenko-signs-long-awaited-law-on-amnestyfor-ukraine-soldiers-with-minor-offence.html.

Peace First, Justice Later. Traditional Justice in Northern Uganda (2005). Retrieved from: http://www. refugeelawproject.org/resources/working-papers/73-peace-first,-justice-later-traditional-justice-innorthern-uganda.html.

"Prosecutor v. Allieu Kondewa (Decision on Preliminary Motion on the Invalidity of the Agreement between the United Nations and the Government of Sierra Leone on the Establishment of the Special Court) (2004), separate opinion of Justice Robertson. Retrieved from: http://www.rscsl.org/Documents/ Decisions/CDF/Appeal/128/SCSL-04-14-T-128.pdf.

"Report of the Secretary General of the United Nations. The rule of law and transitional justice in societies that suffer or have suffered from conflict" (2004). Retrieved from: http://www.ipu.org/splz-e/unga07/ law.pdf.

Sánchez, C.F. (2016). "Manipulating Truths: Media Coverage, Democracy, and the Colombian Referendum”. Retrieved from: https://justiceinconflict.org/2016/10/12/manipulating-truths-media-coveragedemocracy-and-the-colombian-referendum/.

Scharf, M.P. (1999). “The Amnesty Exception to the Jurisdiction of the International Criminal Court”. Cornell International Law Journal 32, p. 507-527.

"Special Court for Sierra Leone Statute". Retrieved from: http://www.rscsl.org/documents.html.

"Special Tribunal for Lebanon". Retrieved from: http://www.stl-tsl.org/en/STL-Documents/Library.

Summary of Colombia's Agreement to End Conflict and Build Peace (2016). Retrieved from: http://www.altocomisionadoparalapaz.gov.co/herramientas/Documents/summary-of-colombias-peace-agreement. pdf.

Šimonović, I. (2003). “Post-Conflict Peace Building: The New Trends”. International Journal of Legal Information 31, p. 251-263.

The Belfast Guidelines on Amnesty and Accountability with Explanatory Guidance (2013). Transitional Justice Institute at the University of Ulster. Retrieved from: www.transitionaljustice.ulster.ac.uk/ documents/TheBelfastGuidelinesonAmnestyandAccountability.pdf. 
"The Massacres of El Mozote and Nearby Places v. El Salvador (Judgment 2012, Merits, reparations and costs)". Retrieved from: www.corteidh.or.cr/docs/casos/articulos/seriec_252_ing1.pdf.

Van Zyl, P. (2005). "Promoting Transitional Justice in Post-Conflict Societies". In Bryden, A., Hänggi, H. (Eds.), Security Governance in Post-Conflict Peacebuilding (p. 23-43), Geneva: Geneva Centre for the Democratic Control of Armed Forces.

Vásquez, J.G. (2016). “Just like the Brexit vote, the Colombian referendum was corrupted by lies”. Retrieved from: https://www.theguardian.com/commentisfree/2016/oct/10/colombian-referendum-farcguerrillas-brexit?CMP=share_btn_fb

Wiatr, K. (2009). "Komisja Prawdy i Pojednania oraz amnestii w RPA - moralne i prawne problem a szanse na pojednanie”. In Żelichowski R. (ed), Świat i Polska wobec globalnych wyzwań. Wybrane zagadnienia, Warsaw: Oficyna Wydawniczo-Poligraficzna Konika.

\section{Author}

Dr hab. Agnieszka Szpak (LLD)

Nicolaus Copernicus University in Toruń, Department of International and European Law Contact details: ul. Batorego 39L, 87-100 Toruń, Poland

e-mail: aszpak@umk.pl. 